\title{
Business Excellence through the Theory of Accountability
}

\author{
P.S. Aithal \\ Professor, College of Management \& Commerce, Srinivas University, Mangalore - 575 001, \\ India \\ OrcidID: 0000-0002-4691-8736; E-mail: psaithal@gmail.com
}

Area of the Paper: Business management.

Type of the Paper: Explorative research based analysis.

Type of Review: Peer Reviewed as per $|\mathrm{C}| \mathrm{O}|\mathrm{P}| \mathrm{E} \mid$ guidance.

Indexed In: OpenAIRE.

DOI: http://doi.org/10.5281/zenodo.4775879

Google Scholar Citation: $\underline{\text { IJCSBE }}$

\section{How to Cite this Paper:}

Aithal, P.S., (2021). Business Excellence through the Theory of Accountability. International Journal of Case Studies in Business, IT, and Education (IJCSBE), 5(1), 88115. DOI: http://doi.org/10.5281/zenodo.4775879.

International Journal of Case Studies in Business, IT and Education (IJCSBE)

A Refereed International Journal of Srinivas University, India.

Crossref DOI : https://doi.org/10.47992/IJCSBE.2581.6942.0103

(C) With Authors.

This work is licensed under a Creative Commons Attribution Non-Commercial 4.0 International License subject to proper citation to the publication source of the work.

Disclaimer: The scholarly papers as reviewed and published by the Srinivas Publications (S.P.), India are the views and opinions of their respective authors and are not the views or opinions of the S.P. The S.P. disclaims of any harm or loss caused due to the published content to any party. 


\title{
Business Excellence through the Theory of Accountability
}

\author{
P. S. Aithal \\ Professor, College of Management \& Commerce, Srinivas University, Mangalore - 575 001, \\ India \\ OrcidID: 0000-0002-4691-8736; E-mail: psaithal@gmail.com
}

\begin{abstract}
Background/Purpose: Theory of Accountability or Theory A is argued to be the best tool for enhancing organizational performance in the $21^{\text {st }}$ century due to the relevance of its motivational and controlling factors with changing competitive environment of organizational business.
\end{abstract}

Objective: To find the suitability and possibility of using the Theory of Accountability to improve organizational business excellence and to know its validity and superiority over other business excellence theories.

Design/Methodology/Approach: Analysis of information collected from various scholarly articles and by using ABCD analysis framework.

Findings/Result: Based on the analysis, it is found that the Theory of Accountability plays a founding stage to assured development of an organization by means of optimum performance through enhanced productivity and highest stakeholders performance leading to achieve business excellence.

Research limitations/implications: The analysis of using Theory of Accountability principles in organizational development in the $21^{\text {st }}$ century complements the objective of organizations to achieve business excellence.

Originality/Value: This paper fulfills a global need on how to achieve business excellence by implementing organizational human accountability.

Paper Type: Explorative research based analysis.

Keywords: Theory of Accountability, Business excellence, Leadership, Role-model, Superior quality through accountability

\section{INTRODUCTION :}

Business is primarily seen as doing any activity with financial profit motivation by individuals or organized group of individuals called organization. Business needs various strategies by individuals or organizations for continued existence [1-2]. These strategies are called survival, sustainable, competition, monopoly, or their mix [3-7]. For long term existence with continued profit, any business has to improve quality or add values from the customer perspective. Organizational Business Excellence is defined as attaining excellence in business strategies, business practices, and stakeholder-related performance by evaluating and validating through proven business excellence models (BEMs) [8] (2008). The BEMs were created using concepts and core values that are deemed crucial in developing extra-ordinary business performance. Attaining business excellence for a long time by improving quality or by adding continuous values to its products or services, or to the method of doing business for efficiency and effectiveness is a challenge to every business in spite of its size. Various theories were developed by many business experts to attain business excellence [9]. Business excellence can be achieved by means of achieving operational and service excellence through improved performance (individual \& organizational) [10] or using innovative technology [11].

In this paper, we made an attempt to review various concepts in business excellence, including organizational performance based business excellence, Quality based business excellence, Value based business excellence, and Customer satisfaction based business excellence. Further, various important business excellence models and frameworks including. Australian Business Excellence Framework Model (ABEM), Baldrige Criteria for Performance Excellence (BCPE), European Foundation of Quality Management (EFQM), Singapore Quality Award Criteria (SQAC), Swedish Institute for Quality, Business excellence models 2.0, are evaluated and summarized. Based on this, the opportunity, 
ability, and possibility of using our new organizational performance theory called Theory of Accountability for achieving organizational business excellence are discussed.

\section{RELATED WORK ON BUSINESS EXCELLENCE :}

\subsection{Organizational Performance based Business Excellence:}

Organizational performance is defined as actual output measured performance against intended performance. Organizational performance is usually internal to the organization in terms of its efficiency, effectiveness, and productivity. Organizational performance can be increased either by improving the efficiency of employees or by systematic automation using suitable technology. Measurement of organizational performance helps to better asset and knowledge management, creation of value, and organizational reputation. Generally, organizational performance depends on the structure of the organization, its leadership, working environment, and internal motivation for employees.

An organization can develop its own business development framework to achieve stronger financial performance, to create an inspiring and visionary leader, to add values to products \& services through innovation, to focus on customer service and satisfaction, to expand market share and revenue, to develop effective business planning processes, to reduce operational cost and increase productivity, to enhance decision making capability and raise capacity to manage change, to engage team based activities to enhance employee performance and satisfaction, and to demonstrate the key stakeholders that the organization has a systematic approach to improve performance and to achieve best practices and excellence.

Philippe Lorino (1997) [12] states that organizational performance deals with activities for cost-value couples instead of focussing only on activities that reduce the cost or the activities to increase the value. This includes all activities that contribute to the achievements of strategic objectives. A business organization is efficient if it has the ability to create economic value added to it positively.

Rolstadas (1998) [13] believes that the performance of an organizational system is a complex relationship involving seven performance criteria called the Sink and Tuttle model, that includes effectiveness, efficiency, quality, productivity, quality of work, innovation and profitability. According to him the Performance is closely related to the achievement of these seven criteria and is regarded as performance objectives. According to Rolstadas, it cannot be established a precise definition of performance because it is dependent on the seven criteria of performance, that cannot be clearly defined for an individual organization.

In 2007, Folan pointed out three priorities to attain business excellence which include (1) Organizational performance should be analysed based on the performance of each entity within the limits of the environment in which they decide to operate, (2) Organizational performance is always linked to one or several objectives set by the entity whose performance is to be analysed, (3) Organizational performance is reduced to the relevant and recognizable features. According to Folan's theory, performance is influenced by the environment, the objectives to be achieved and the relevant and recognizable features [14].

According to Richard et al. (2009) [15] the organizational performance consists of three outcomes of an organization that include (1) financial performance like profits, return on assets, return on investment, etc. (2) market performance including sales, market share, etc. and (3) Shareholder return including share price, shareholder return, economical value added, etc.

Elena-Iuliana et al. (2016) reviewed the concept of performance starting from both Marston's motto "Don't lower your expectations to meet your performance. Raise your level of performance to meet your expectations" and the opinions, views, and definitions expressed in the scholarly literature by various authors [16].

According to Puteh, F., (2016) [17] to achieve organizational excellence, the organization should establish a set of crucial competencies or "core competencies" among employees regardless of their 
roles, positions, and levels. These core competencies namely functional competency, communication competency, leadership competency, and cognitive competency are essential to perform their jobs well.

Tickle, M., et al. (2016), with the objective of how organizations successfully deploy business excellence by comparing the tools and strategies implemented by organizations at different levels of business excellence maturity, the study has shown that on average, organizations with higher BE maturity outperform their less mature counterparts. The study also revealed that organizations with a high business excellence maturity were more likely to use specific tools and were more likely to use some of these tools more effectively. Finally, the study identified differences in strategic approaches to business excellency between organizations with high and low business excellency maturity [18]. Table 1 lists some of related scholarly research on organizational performance based business excellence.

Table 1 : Published work on organizational performance based on BE

\begin{tabular}{|c|c|c|c|}
\hline S. No. & Area & Issue & Reference \\
\hline 1 & $\begin{array}{l}\text { Organizational business } \\
\text { excellence Model }\end{array}$ & $\begin{array}{l}\text { By measuring leadership } \\
\text { excellence. }\end{array}$ & $\begin{array}{l}\text { Kanji, G. K., et al. } \\
(2001) .[19]\end{array}$ \\
\hline 2 & $\begin{array}{l}\text { Business excellence in } \\
\text { organizations }\end{array}$ & Implementation. & $\begin{array}{l}\text { Kanji, G. K. (2002). } \\
{[20]}\end{array}$ \\
\hline 3 & $\begin{array}{l}\text { The relationship between } \\
\text { business excellence and } \\
\text { performance }\end{array}$ & $\begin{array}{l}\text { Empirical proof of Kanji's } \\
\text { leadership excellence model. }\end{array}$ & $\begin{array}{l}\text { Oakland, J. S., et al. } \\
\text { (2008). [21] }\end{array}$ \\
\hline 4 & Organizational excellence & $\begin{array}{l}\text { Based on organizational integrity } \\
\text { and leadership behaviour }\end{array}$ & $\begin{array}{l}\text { Hadi, A. A., et al. } \\
\text { (2019). [22] }\end{array}$ \\
\hline 5 & $\begin{array}{l}\text { Organizational business } \\
\text { excellence }\end{array}$ & $\begin{array}{l}\text { Implementing business } \\
\text { excellence by organizationally } \\
\text { referenced indicators of outcome } \\
\text { improvement and process } \\
\text { difficulty. }\end{array}$ & $\begin{array}{l}\text { Bauer, J., et al. (2005). } \\
\text { [23] }\end{array}$ \\
\hline 6 & $\begin{array}{l}\text { Personal and organizational } \\
\text { excellence }\end{array}$ & $\begin{array}{l}\text { By Servant Leadership, Learning } \\
\text { to Serve, Serving to Lead, } \\
\text { Leading to Transform }\end{array}$ & $\begin{array}{l}\text { Sendjaya, S. (2015). } \\
{[24]}\end{array}$ \\
\hline 7 & $\begin{array}{l}\text { Business Excellence-Case } \\
\text { Study }\end{array}$ & $\begin{array}{l}\text { Employees' Empowerment as an } \\
\text { Approach }\end{array}$ & $\begin{array}{l}\text { Boussalem, A. (2015). } \\
\text { [25] }\end{array}$ \\
\hline 8 & $\begin{array}{l}\text { Achieving Business } \\
\text { Excellence }\end{array}$ & Managing Men at Workplace & $\begin{array}{l}\text { Badruddin, A. (2016). } \\
\text { [26] }\end{array}$ \\
\hline 9 & $\begin{array}{l}\text { Organizational business } \\
\text { excellence }\end{array}$ & $\begin{array}{l}\text { Elements of organizational } \\
\text { culture }\end{array}$ & $\begin{array}{l}\text { Meško Štok, Z., } \\
\text { (2010). [27] }\end{array}$ \\
\hline
\end{tabular}

\subsection{Quality based Business Excellence:}

Business excellence can be also achieved by improving the quality of output product/service in an organization. Some of the quality factors include top management commitment, social responsibility, customer focus and satisfaction, Quality information and performance measurement, benchmarking, employee empowerment, product and service design, process management, continuous improvement, quality assurance, Just in time, and flexibility [28]. Quality management concepts are used for improving competitiveness, efficiency, and profitability. New concepts like the six sigma approach and lean production are used to measure and improve the quality of output product/service [29]. Table 2 lists some of related scholarly research on quality based business excellence.

Table 2 : Published work on organizational performance based on quality

\begin{tabular}{|l|l|l|l|}
\hline S. No. & Area & Issue & Reference \\
\hline 1 & Total quality management & $\begin{array}{l}\text { Sustaining business excellence } \\
\text { through a framework of best } \\
\text { practices }\end{array}$ & $\begin{array}{l}\text { Lee, P. M. (2002). } \\
{[30]}\end{array}$ \\
\hline 2 & Attaining business & The three-dimensional approach & Androniceanu, A. \\
\hline
\end{tabular}




\begin{tabular}{|l|l|l|l|}
\hline & excellence & $\begin{array}{l}\text { of Total Quality Management, an } \\
\text { essential strategic option }\end{array}$ & (2017). [31] \\
\hline 3 & $\begin{array}{l}\text { A framework to achieve } \\
\text { business excellence }\end{array}$ & $\begin{array}{l}\text { essential characteristics of the } \\
\text { TQM philosophy by } \\
\text { comparing the work of ten } \\
\text { notable authors in the field }\end{array}$ & $\begin{array}{l}\text { Hafeez, K., et al. } \\
\text { (2006). [32] }\end{array}$ \\
\hline 4 & $\begin{array}{l}\text { Quality through Circle of } \\
\text { Satisfaction }\end{array}$ & $\begin{array}{l}\text { Delight customers, satisfy } \\
\text { employees and streamline } \\
\text { processes }\end{array}$ & $\begin{array}{l}\text { Vora, M. K. (2002). } \\
\text { [33] }\end{array}$ \\
\hline 5 & $\begin{array}{l}\text { Total quality management } \\
\text { and business excellence }\end{array}$ & $\begin{array}{l}\text { The best practices at Toyota } \\
\text { Motor Corporation }\end{array}$ & $\begin{array}{l}\text { Toma, S. G., (2017). } \\
\text { [34] }\end{array}$ \\
\hline 6 & $\begin{array}{l}\text { Gaining business } \\
\text { excellence through total } \\
\text { quality management }\end{array}$ & $\begin{array}{l}\text { A Finnish case study on } \\
\text { Leadership strategies }\end{array}$ & $\begin{array}{l}\text { Savolainen, T. (2000). } \\
\text { [35] }\end{array}$ \\
\hline 8 & $\begin{array}{l}\text { From quality to excellence } \\
\text { in the 21st century }\end{array}$ & $\begin{array}{l}\text { Explores the development of } \\
\text { Total Quality Management } \\
\text { and Business Excellence }\end{array}$ & $\begin{array}{l}\text { Oakland, J. (2005). } \\
\text { [36] }\end{array}$ \\
\hline $\begin{array}{l}\text { Quality management and } \\
\text { business excellence }\end{array}$ & $\begin{array}{l}\text { Developing techniques and tools } \\
\text { of business excellence which lead } \\
\text { the organization to outstanding } \\
\text { performance on quality }\end{array}$ & Dinu, V. (2017). [37] \\
\hline
\end{tabular}

\subsection{Value based Business Excellence:}

Business excellence is also considered as a set of fundamental concepts or values that support the measurement, management, and delivery of competitive performance at the world class level. It stresses the importance firm specific core values for achieving operational excellence, eminent winning strategy, capability to adopt changes, to raise unique voice [38], and organizational culture [39-40]. The procedure to create value from stakeholders point of view consists of identifying the relevant stakeholders group, assessing their stake and relevance, determining how much their needs and expectations are met, and improving organizational policies and priorities towards fulfilling stakeholders interests.

The internal core values like leadership, constant innovation, intellectual property, and excellent business process management and the external core values like Customer satisfaction, Brand, Goodwill, Internationalization, and public perception.

As per Talwar B. (2009) [41], some of the common core values considered in 16 business excellence models are (1) customer focus; (2) continuous learning, (3) innovation and improvement; (4) employee involvement and development; (5) partnership development; (6) systems; (7) process-based management; (8) agility; and (9) social responsibility. Table 3 lists some of the related scholarly research on value based business excellence.

Table 3 : Published work on organizational performance based on value creation

\begin{tabular}{|l|l|l|l|}
\hline S. No. & Area & Issue & Reference \\
\hline 1 & $\begin{array}{l}\text { Evolving path of TQM: } \\
\text { towards business } \\
\text { excellence and stakeholder } \\
\text { value }\end{array}$ & $\begin{array}{l}\text { The coordinated and systematic } \\
\text { development of TQM basic factors } \\
\text { helps to create stakeholder value }\end{array}$ & $\begin{array}{l}\text { Mele, C., et al. } \\
\text { (2006). [42] }\end{array}$ \\
\hline $\begin{array}{l}\text { Model for sustainable } \\
\text { business excellence }\end{array}$ & $\begin{array}{l}\text { Aligned with conscious capitalism, } \\
\text { constructive capitalism, shared } \\
\text { value, values-driven organizations } \\
\text { and corporate governance. }\end{array}$ & $\begin{array}{l}\text { Jabnoun, N. (2019). } \\
\text { [43] }\end{array}$ \\
\hline 3 & $\begin{array}{l}\text { Intellectual capital and } \\
\text { value creation }\end{array}$ & $\begin{array}{l}\text { The influence of representative } \\
\text { variables of human capital and }\end{array}$ & Díez, (2010). [44] \\
\hline
\end{tabular}




\begin{tabular}{|c|c|c|c|}
\hline & & $\begin{array}{l}\text { structural capital on the creation of } \\
\text { business value in Spanish firms }\end{array}$ & \\
\hline 4 & $\begin{array}{l}\text { Achieving business } \\
\text { excellence }\end{array}$ & $\begin{array}{l}\text { Managerial and value-creation } \\
\text { efficiencies of the insurance } \\
\text { companies }\end{array}$ & $\begin{array}{l}\text { Nourani, M., et al. } \\
\text { (2017). [45] }\end{array}$ \\
\hline 5 & $\begin{array}{l}\text { Achieving business } \\
\text { excellence }\end{array}$ & Using social dimension & $\begin{array}{l}\text { Hardjono, T. W., et } \\
\text { al. (2001). [46] }\end{array}$ \\
\hline 6 & $\begin{array}{l}\text { Achieving business } \\
\text { excellence }\end{array}$ & Corporate social responsibility & $\begin{array}{l}\text { Sharma, A. K., et al. } \\
(2005) \text {. [47] }\end{array}$ \\
\hline 7 & $\begin{array}{l}\text { Value creation through } \\
\text { strategic acquisitions, } \\
\text { simultaneous expansion, } \\
\text { and combination of cost- } \\
\text { efficiency with a high- } \\
\text { quality focus }\end{array}$ & $\begin{array}{l}\text { Three types of critical capabilities: } \\
\text { (1) an orientation towards } \\
\text { experimenting with and exploiting } \\
\text { new business opportunities; } \\
\text { (2) a balanced way of using } \\
\text { resources; and } \\
\text { (3) achieving coherence between an } \\
\text { active and clear leadership, a strong } \\
\text { organizational culture, and } \\
\text { employee commitment. }\end{array}$ & $\begin{array}{l}\text { Achtenhagen, L., et } \\
\text { al. (2013). [48] }\end{array}$ \\
\hline 8 & $\begin{array}{l}\text { Theoretical model depicting } \\
\text { the connections between } \\
\text { intellectual capital, } \\
\text { knowledge management } \\
\text { practices and organizational } \\
\text { performance outcomes. }\end{array}$ & $\begin{array}{l}\text { Four models concerning the } \\
\text { interaction of IC assets and KM } \\
\text { practices in value creation } \\
\text { presented. }\end{array}$ & $\begin{array}{l}\text { Kianto, A., et al. } \\
\text { (2014). [49] }\end{array}$ \\
\hline 9 & $\begin{array}{l}\text { Exploring the complexities } \\
\text { of value creation }\end{array}$ & The role of engagement strength & $\begin{array}{l}\text { Scholer, A. A., et al. } \\
\text { (2009). [50] }\end{array}$ \\
\hline 10 & Business Excellence 2.0. & $\begin{array}{l}\text { Include the quality movement and } \\
\text { the different types of business logics } \\
\text { together, such as exchange logic, } \\
\text { steering logic, value creation logic, } \\
\text { business interaction logic, } \\
\text { responsibility logic and } \\
\text { communication logic. }\end{array}$ & $\begin{array}{l}\text { Enquist, B., et al. } \\
\text { (2015). [51] }\end{array}$ \\
\hline 11 & $\begin{array}{l}\text { Value creation through } \\
\text { stakeholder synergy }\end{array}$ & $\begin{array}{l}\text { A single strategic action (1) } \\
\text { increases } \\
\text { types of value for two or more } \\
\text { essential stakeholder groups } \\
\text { simultaneously, and (2) does not } \\
\text { reduce the value already received by } \\
\text { any other essential stakeholder } \\
\text { group. }\end{array}$ & $\begin{array}{l}\text { Tantalo, C., et al. } \\
\text { (2016). [52] }\end{array}$ \\
\hline 12 & $\begin{array}{l}\text { Total business excellence-a } \\
\text { new management model for } \\
\text { operationalizing excellence }\end{array}$ & $\begin{array}{l}\text { Ten critical success factors: } \\
\text { products, financials, stakeholders, } \\
\text { employees, leadership, societal, } \\
\text { operational, innovation, alignment, } \\
\text { and ethical excellence. }\end{array}$ & $\begin{array}{l}\text { Ferdowsian, M. C. } \\
\text { (2016). [53] }\end{array}$ \\
\hline
\end{tabular}

\subsection{Business Excellence through Customer Satisfaction and delight :}

Business excellence in some cases can be achieved by satisfying customers as well as by delighting them. Satisfaction has many levels of completing their expectations whereas delight is the pinnacle of satisfaction and goes above the expectations. Business organizations are struggling to meet customer expectations and to delight them. According to McKinsey study, $3 \mathrm{C}$ 's of customer satisfaction are Consistency of customer journey, consistency of customer emotion, and Consistency in customer 
communication. Customer satisfaction can be quantitatively measured using the Structural equation model developed by Fornell (1992) called the national customer satisfaction barometer [54]. This model is based on representing a conceptual network of various processes with the goal of measuring the customer satisfaction index. In 1998 Kanji, G. K. [9] developed a structural business excellence model using customer satisfaction as a critical success factor. The model measures 14 latent interrelated variables drawn using various quality dimensions. Table 4 lists some of related scholarly research on customer satisfaction and delight based business excellence.

Table 4 : Published work on organizational performance based on Customer Satisfaction and delight

\begin{tabular}{|l|l|l|l|}
\hline S. No. & Area & Issue & Reference \\
\hline 1 & $\begin{array}{l}\text { Business excellence in } \\
\text { hotel industry }\end{array}$ & $\begin{array}{l}\text { From customer satisfaction to } \\
\text { customer delight }\end{array}$ & $\begin{array}{l}\text { Torres, E. N., et al. } \\
\text { (2013). [55] }\end{array}$ \\
\hline 2 & $\begin{array}{l}\text { Ensuring customer delight: } \\
\text { A quality approach to } \\
\text { excellence in management }\end{array}$ & $\begin{array}{l}\text { Student satisfaction survey is used } \\
\text { to study satisfaction and delight } \\
\text { among students of management in } \\
\text { the national capital region of India. }\end{array}$ & $\begin{array}{l}\text { Popli, S. (2005). } \\
\text { [56] }\end{array}$ \\
\hline 3 & $\begin{array}{l}\text { Business excellence model } \\
\text { through customer } \\
\text { satisfaction }\end{array}$ & $\begin{array}{l}\text { Business Excellence Index (BEI) } \\
\text { for a group of companies is given } \\
\text { using this model }\end{array}$ & $\begin{array}{l}\text { Kanji, G. K., et al. } \\
\text { (2000). [57] }\end{array}$ \\
\hline 5 & $\begin{array}{l}\text { Quality management and } \\
\text { business excellence, } \\
\text { customers and stakeholders }\end{array}$ & $\begin{array}{l}\text { What influence in the organizations } \\
\text { on the quality movement and } \\
\text { quality practice }\end{array}$ & $\begin{array}{l}\text { Klefsjö, B., et al. } \\
\text { (2008). [58] }\end{array}$ \\
\hline 6 & $\begin{array}{l}\text { Tustomer satisfaction in the } \\
\text { The implications of all-inclusive } \\
\text { pricing system in total quality } \\
\text { management and business } \\
\text { excellence }\end{array}$ & Koc, E. (2006). [59] \\
\hline concepts and realization of & $\begin{array}{l}\text { Dimensions and elements of } \\
\text { customer delight using various } \\
\text { theories. }\end{array}$ & $\begin{array}{l}\text { Marquardt, A. } \\
\text { (2015). [60] }\end{array}$ \\
\hline
\end{tabular}

\section{OBJECTIVES OF THE PAPER :}

In the process of improving business excellence both incrementally and radically, the following objectives are drawn :

(1) To update the concept of business excellence by reviewing related scholarly work.

(2) To identify the concept of business excellence from different stakeholders' points of view.

(3) To discuss various business excellence models and frameworks.

(4) To propose new methods of achieving business excellence.

(5) To discuss the suitability and possibility of using the Theory of Accountability to improve organizational business excellence.

(6) To Compare Theory of Accountability \& Baldrige Criteria for Performance Excellence

\section{THE CONCEPT OF BUSINESS EXCELLENCE FROM STAKEHOLDERS POINT OF VIEW :}

Business excellence is a status of the business performance of a company in a given industry from the frame of reference of its stakeholders including the whole society. In practice business excellence based on organizational performance is related to business excellence from stakeholders' point of view. An organization can fulfil its long-term objectives by achieving business excellence. Ideally, business excellence is a stage where all stakeholders of the organization get complete satisfaction and delight, and the organization will have an infinite amount of goodwill from stakeholder and society point of view.

Business excellence does not mean a maximum profit or lower priced products, but it is a way of achieving excellence in business in a complex approach from an economically, technically, and socially point of view. Business excellence of a company is an exemplary situation where success, profit for a 
long period of time, and correctly and efficiently adapts to the demands of the socio-economic environment [61]. As shown in the block diagram (Figure 1), attaining business excellence needs reaching the pinnacle of performance in organizational objectives from its stakeholders including its managerial executives, suppliers, employees, and customers.

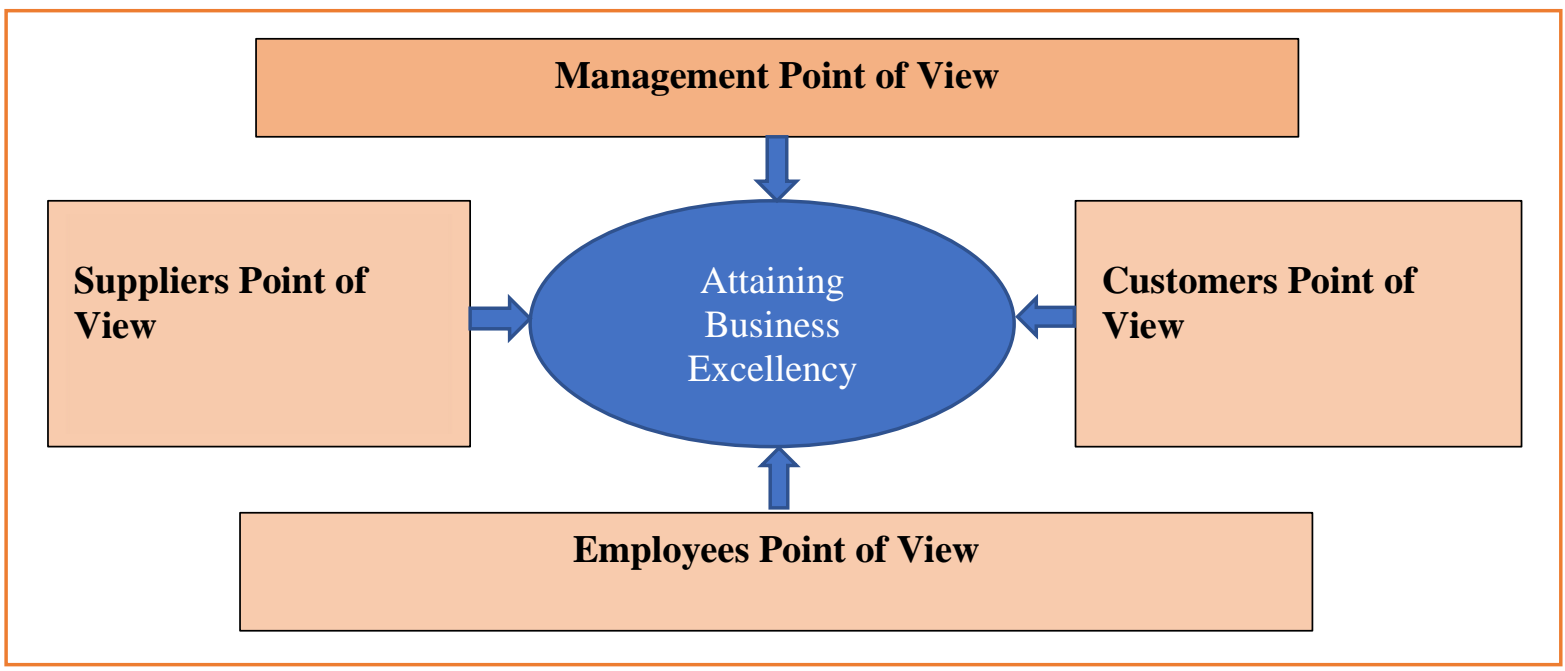

Fig. 1 : Attainment of business excellence from Stakeholder point of views

\subsection{Business Excellence from a Management point of view:}

All administrators of a business firm expect the following characteristics from their business to achieve business excellence:

(1) Growth of assets

(2) No further investment

(3) Standardization of products/services

(4) Operational and performance excellence

(5) Achieving monopoly in products or services or in business model

(6) Customer and supplier satisfaction \& continuation

(7) Effective utilization of resources

(8) Distinguishable quality and features of business entities

(9) Admired and commanding leadership \& control

(10) Global expansion of business and acceptability by stakeholders

(11) Assured success

\subsection{Business Excellence from Employee point of view :}

Achieving business excellence in an organization from the frame of reference of employees of the organization are:

(1) Enhancing the goodwill of the organization

(2) Improving productivity through smart work

(3) Enhanced profit and employee benefits

(4) Employee motivation \& empowerment

(5) Performance based employee accountability

(6) Open system with internal organizational human dignity

(7) Satisfied employees and long term sustainability

(8) Visionary and effective leadership

\subsection{Business Excellence from Supplier Point of view :}

(1) Continuous improvement in raw material consumption

(2) Up to date in payments

(3) Automation in order processing through an integrated system

(4) Business expansion with combined growth

(5) Business sustainability through ethical practices 
(6) Emotional connection

\subsection{Business Excellence from a Customer point of view :}

(1) Standardized products or services

(2) Quality of products or services

(3) Satisfaction \& delight

(4) Product durability or Service repeatability

(5) After sales support

(6) Value addition

(7) Customer centered approach

(8) Emotional connection

\section{BUSINESS EXCELLENCE - RELEVANT APPROACHES :}

Though many business excellence models are proposed and used by many organizations, some of the models are recognized and generally accepted in many countries. They are Australian business excellence model, American business excellence model called Baldrige model, European business excellence model, Singapore business excellence model, Swedish business excellence model, Modern business excellence model 2.0 [51], etc. Each model has its own merits and demerits.

\subsection{Australian Business Excellence Framework Model (ABEM):}

Australian Business Excellence Framework Model (ABEM) has the following Categories while evaluating the business excellence of an organization [62], [51]:

- Leadership - Importance of visionary and role model as a leader with strategy implementing ability.

- Customers and Stakeholders - Importance of Customer satisfaction \& stakeholders' involvement.

- Strategy and Planning - Importance of planning and implementation of right strategy at right time.

- People - Employee's contribution and involvement.

- Information and Knowledge - Right information at right time for right decision making by managers at the right time to encash opportunities.

- Process Management, Improvement, and Innovation - To differentiate products or services through new features, business models, or technology.

- Results and Sustainable Performance - For sustained profit \& growth.

Australian Business Excellence Framework Model highlights on leadership and helps organizations to achieve and maintain high levels of performance through lead by example, continuously improve the system, understand what markets and customers value, etc. and hence provides :

(1) The foundation to develop an organization by focussing on sustainable performance.

(2) Offers a solid structure for integrating all improvement initiatives and organizational decisionmaking.

(3) Helps to achieve organizational goals and deliver increased customer and stakeholder perception of value.

(4) Provides a performance benchmarking program for organizations.

\subsection{American Baldrige Criteria for Performance Excellence (BCPE) :}

In 1987, U.S. Congress constituted a business excellence award to the American companies to promote performance excellence and provides global leadership in the learning and sharing of successful strategies and performance practices, principles, and methodologies. They promoted American Business excellence model which is developed and promoted in the name of Malcolm Baldrige. This business excellence model is suggested initially in 1988, revised model in 1992, and further revised model in 1997 [63, 64].

The Baldrige Criteria for Performance Excellence provide a framework that any organization can use to improve overall performance. The Criteria/constructs are organized into the following seven categories: 
(1) Leadership - Examines how senior executives guide the organization and how the organization addresses its responsibilities to the public and practices good citizenship.

(2) Strategic Planning - Examines how the organization sets strategic directions and how it determines key action plans.

(3) Customer Focus - Examines how the organization determines requirements and expectations of customers and markets; builds relationships with customers; and acquires, satisfies, and retains customers.

(4) Measurement, Analysis, and Knowledge Management - Examines the management, effective use, analysis, and improvement of data and information to support key organization processes and the organization's performance management system.

(5) Workforce Focus - Examines how the organization enables its workforce to develop its full potential and how the workforce is aligned with the organization's objectives.

(6) Operations Focus - Examines aspects of how key production/delivery and support processes are designed, managed, and improved.

(7) Results - Examines the organization's performance and improvement in its key business areas: customer satisfaction, financial and marketplace performance, human resources, supplier and partner performance, operational performance, and governance and social responsibility. The category also examines how the organization performs relative to competitors.

The Malcolm Baldrige National Quality Award (MBNQA) has evolved from a means of recognizing and promoting exemplary quality management practices to a comprehensive framework for world-class performance, widely used as a model for improvement. Table 5 gives the comparison of constructs of Baldrige revised models.

Table 5 : Comparison of Constructs of Baldrige revised models [65, 66]

\begin{tabular}{|l|l|l|l|}
\hline S. No. & Baldrige 1988 path model & Baldrige 1992 path model & \multicolumn{1}{|c|}{$\begin{array}{c}\text { Baldrige 1997 path } \\
\text { model }\end{array}$} \\
\hline 1 & Leadership & Leadership & Leadership \\
\hline 2 & Information \& Analysis & Information \& Analysis & Information \& Analysis \\
\hline 3 & Strategic Quality Planning & $\begin{array}{l}\text { Management of Process } \\
\text { Quality }\end{array}$ & Strategic Planning \\
\hline 4 & HR Utilization & $\begin{array}{l}\text { HR Development and } \\
\text { Management }\end{array}$ & $\begin{array}{l}\text { HR Development \& } \\
\text { Management }\end{array}$ \\
\hline 5 & $\begin{array}{l}\text { Quality of Products and } \\
\text { Services }\end{array}$ & $\begin{array}{l}\text { Strategic Quality Planning } \\
\text { Customer \& Market } \\
\text { Focus }\end{array}$ \\
\hline 6 & $\begin{array}{l}\text { Results of Quality of } \\
\text { Products and Services }\end{array}$ & $\begin{array}{l}\text { Quality \& Operational } \\
\text { Results }\end{array}$ & Process Management \\
\hline 7 & $\begin{array}{l}\text { Customer satisfaction } \\
\text { satisfaction }\end{array}$ & Business Results \\
\hline
\end{tabular}

The Baldrige performance excellence criteria are a framework that any organization can use to improve overall performance. These criterions leads to following core values and concepts which are considered as foundation of Baldrige framework :

(1) Systems perspective.

(2) Visionary leadership.

(3) Customer-centered excellence.

(4) Valuing people in the organization including partners.

(5) Agility and resilience.

(6) Organizational learning.

(7) Focus on success, innovation, creating value, and future.

(8) Management by fact. 
5.3 European Foundation for Quality Management (EFQM) Excellence Model (EFQM, 2009).

Business excellence model of European Foundation for Quality Management consist of nine criteria listed below :

(1) Leadership,

(2) People,

(3) Policy and strategy,

(4) Partnerships and resources,

(5) Processes,

(6) People results,

(7) Customer results,

(8) Society results, and

(9) Key performance results

The concepts and core values of business excellence are similar between the various models and for two most popular models Baldrige Criteria for Performance Excellence (BCPE) and European Foundation of Quality Management (EFQM) are listed in table 6 [67].

Table 6 : Comparison of constructs (concepts and core values) of Australian, American (BCPE) and EFQM [67]

\begin{tabular}{|c|c|c|c|}
\hline S. No. & $\begin{array}{l}\text { American Business } \\
\text { Excellence Model (11C) }\end{array}$ & $\begin{array}{l}\text { Australian Business } \\
\text { Excellence Model (7C) }\end{array}$ & $\begin{array}{l}\text { EFQM Business } \\
\text { Excellence Model (8C) }\end{array}$ \\
\hline 1 & Visionary leadership & Leadership as role model & $\begin{array}{l}\text { Creating a Sustainable } \\
\text { Future }\end{array}$ \\
\hline 2 & Customer-driven excellence & $\begin{array}{l}\text { Focus on Customers and } \\
\text { Stakeholders }\end{array}$ & $\begin{array}{lll}\begin{array}{l}\text { Adding } \\
\text { Customers }\end{array} & \text { Value } & \text { for } \\
\end{array}$ \\
\hline 3 & $\begin{array}{l}\text { Organizational and personal } \\
\text { learning }\end{array}$ & Strategy and Planning & $\begin{array}{l}\text { Developing Organizational } \\
\text { capability }\end{array}$ \\
\hline 4 & $\begin{array}{l}\text { Valuing workforce members } \\
\text { and partners }\end{array}$ & $\begin{array}{l}\text { People (Contribution \& } \\
\text { involvement) }\end{array}$ & $\begin{array}{l}\text { Succeeding through the } \\
\text { Talent of People }\end{array}$ \\
\hline 5 & Agility and resilience & - & Managing with Agility \\
\hline 6 & Focus on the future & $\begin{array}{l}\text { Information } \\
\text { Knowledge }\end{array}$ & $\begin{array}{l}\text { Harnessing Creativity \& } \\
\text { Innovation }\end{array}$ \\
\hline 7 & Managing for innovation & $\begin{array}{l}\text { Results and Sustainable } \\
\text { Performance }\end{array}$ & $\begin{array}{l}\text { Sustaining Outstanding } \\
\text { Results }\end{array}$ \\
\hline 8 & Management by fact & $\begin{array}{lr}\text { Process } & \text { Management, } \\
\text { Improvement } & \text { and } \\
\text { Innovation } & \end{array}$ & $\begin{array}{l}\text { Leading with Vision, } \\
\text { Inspiration \& Integrity }\end{array}$ \\
\hline 9 & Societal responsibility & - & - \\
\hline 10 & $\begin{array}{l}\text { Focus on results and creating } \\
\text { value }\end{array}$ & - & - \\
\hline 11 & Systems perspective & - & - \\
\hline
\end{tabular}

EFQM describes the continuous improvement of the quality of products and services from customers perspectives. Accordingly, managers and leaders in organizations set up ways of working for efficient performance by involving everyone in the continuous improvement process of meeting the internal and external needs of customers.

\subsection{Singapore Quality Award Criteria (SQAC) -}

The Singapore Quality Award (SQA) framework is proposed and developed by SPRING Singapore to motivate Singapore's organizations to improve quality standards and to achieve business excellence. The award was initiated to Singapore's organizations to showcase their commitment to world-class nosiness excellence. The framework consists of seven quality components and nine core values and concepts as listed in table 7 . 
Table 7 : Seven components and nine core values and concepts of SQA

\begin{tabular}{|l|l|l|}
\hline S. No. & Quality components & Core values and concepts \\
\hline 1 & Leadership & Visionary leadership \\
\hline 2 & Planning & Customer driven quality \\
\hline 3 & Information & Innovation focus \\
\hline 4 & People & Valuing people \& Partners \\
\hline 5 & Processes & Agility \\
\hline 6 & Customers Focus & Knowledge driven system \\
\hline 7 & Results & Societal responsibility \\
\hline 8 & - & Results orientation \\
\hline 9 & - & Systems perspective \\
\hline
\end{tabular}

As seen in table 4, the Singapore Quality Award (SQA) framework focus on visionary leadership, customer driven quality planning, customer feedback based information for further improvement, dedicated, committed and highly skilled workforce, automated processes, and result oriented service to achieve business excellence [68].

\subsection{Business excellence models of Swedish Institute for Quality (SIQ):}

SIQ Management model consists of five criteria for evaluation of an organization for its business excellence and the metric evaluation is for 1000 scores [69]. These criteria along with their components and weightage scores are listed in table 8 .

Table 8 : SIQ Management model with evaluation criteria for total 1,000 scores

\begin{tabular}{|c|c|c|c|}
\hline S. No. & SIQ Criteria & Components & Scores \\
\hline \multirow[t]{4}{*}{1} & \multirow{4}{*}{$\begin{array}{l}\text { Customers \& } \\
\text { Stakeholders } \\
(150)\end{array}$} & Understanding needs and expectations & 50 \\
\hline & & Create value with them & 50 \\
\hline & & Create promises to them & 20 \\
\hline & & Follow up the level of satisfaction & 30 \\
\hline \multirow[t]{4}{*}{2} & \multirow{4}{*}{$\begin{array}{l}\text { Management } \\
\text { (125) }\end{array}$} & Plan for sustainable organization & 30 \\
\hline & & Lead it for sustainability & 40 \\
\hline & & Lead coworkers & 30 \\
\hline & & Lead processes & 25 \\
\hline \multirow[t]{3}{*}{3} & \multirow{3}{*}{$\begin{array}{l}\text { Coworkers } \\
(125)\end{array}$} & Develop coworker skills & 40 \\
\hline & & Promote creativity and participation & 45 \\
\hline & & $\begin{array}{l}\text { Follow up coworkers and create good } \\
\text { working environment }\end{array}$ & 40 \\
\hline \multirow[t]{2}{*}{4} & \multirow{2}{*}{$\begin{array}{l}\text { Operational processes } \\
(100)\end{array}$} & Establish processes & 30 \\
\hline & & Improve processes & 70 \\
\hline \multirow[t]{5}{*}{5} & \multirow{5}{*}{$\begin{array}{l}\text { Results } \\
(500)\end{array}$} & Results of Customers \& Stakeholders & 100 \\
\hline & & Results of coworkers & 100 \\
\hline & & Results of Social sustainability & 100 \\
\hline & & Results of environmental sustainability & 100 \\
\hline & & Results of financial sustainability & 100 \\
\hline
\end{tabular}

Swedish Institute for Quality framework gives focus on results of satisfactory service provided by the organization with the direction of its leader to Customers \& Stakeholders through dedicated coworkers by improving operational processes and financial sustainability of the organization along with its environmental and social sustainability.

\subsection{Business excellence models 2.0 :}

By assessing these in relation to today's new business landscape, the authors suggest that emphasizing issues such as stakeholder co-creation of value, stakeholder dialogue, service innovation, service logic, business ethics and different views on resource integration can alter the view of quality improvement 
from economic, social and environmental perspectives, in turn, leading to Business Excellence 2.0 [51].

\subsection{New Proposals on achieving Business Excellence :}

Business excellence is a stage of sustainable optimum performance within the constraints. Organizations can achieve business excellence by focussing on internal performance based on their long-term objectives. Apart from the above theories and models which support organizations to achieve excellence, the following three more methods are also helping organizations both in production and service industries to achieve performance excellence.

(1) Business performance excellence through Theory of Accountability to enhance the individual \& team performance [70 - 75].

(2) Business performance excellence through complete automation of business processes by means of Innovative use of Universal Technologies [76-80].

(3) Business performance excellence through an emotional connection with stakeholders by adopting the Essence of Indian Knowledge, Culture, and Tradition [81-82].

The internal productivity and performance of an organization can shoot up by the effective implementation of the Theory of accountability or by automating every process using intelligent or super-intelligent machines using universal technologies or by improving and Indianizing organizational culture using Indian philosophy. In this paper, it is analyzed how the Theory of Accountability can be used for achieving business excellence in organizations in any country.

\section{THEORY OF ACCOUNTABILITY (THEORY A) :}

Educating and motivating the internal stakeholders to understand the business objectives, to involve individually and in groups in quality improvement processes, enhancing self-contribution through inspired by role-models, ensuring the performance through continuous monitoring from the system, and finally, accountability-based incentives for their contribution to organizational excellence are some of the constructs of theory of accountability. The theory of accountability deals with improving the efficiency, effectiveness, and productivity of an organization by implementing the principles of responsibility and accountability on various designated employees, thereby, contributing to organizational excellence. By optimizing employee's performance through a systematic strategy, organizations can achieve business excellence. Accountability is the only criterion which makes a man (leader/manager/employee) to perform optimally to fulfil his responsibility completely.

Components of Theory of Accountability :

Figures 2 and 3 depict various components and constructs of Theory A [72].

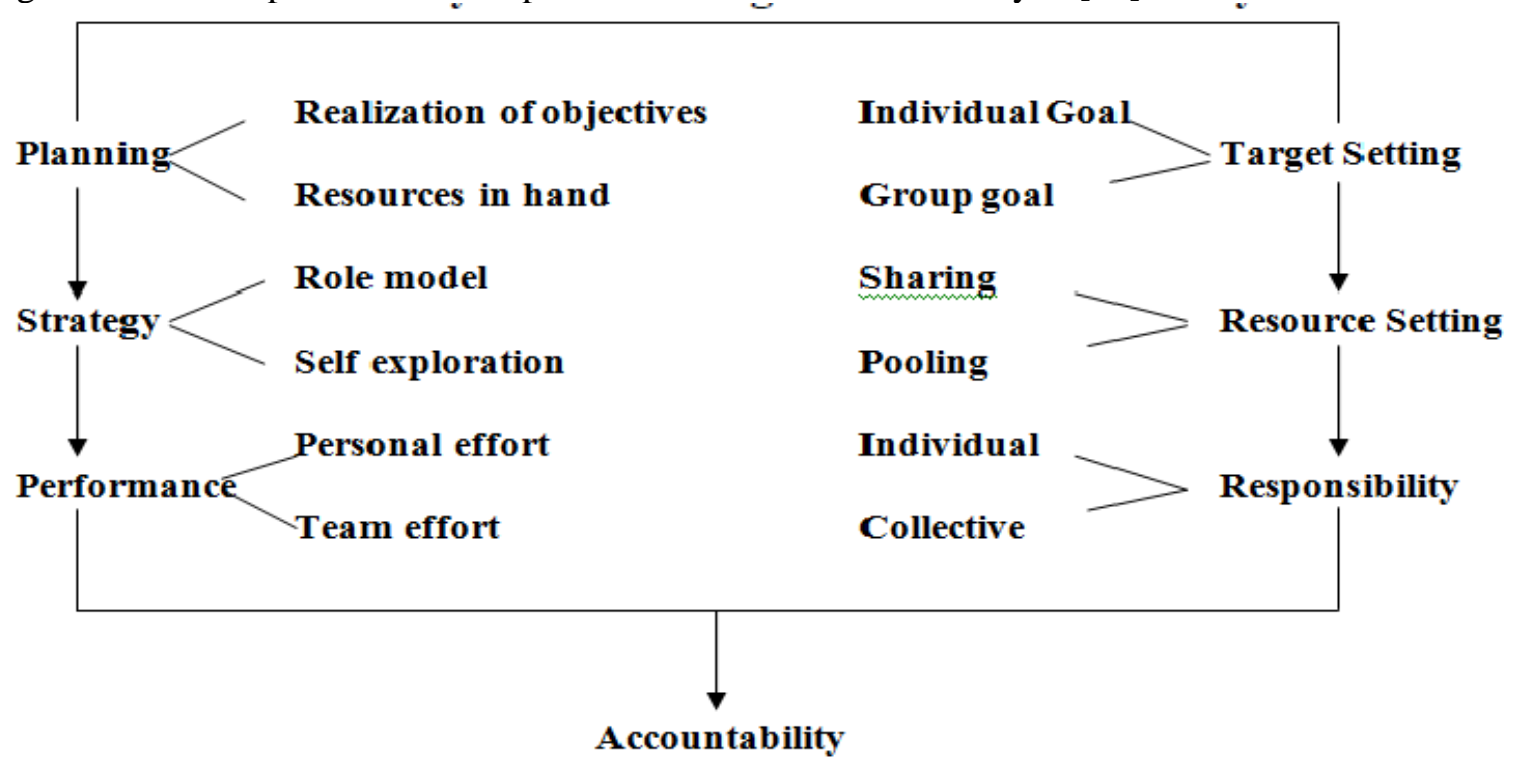

Fig. 2: Components of Theory of Accountability for organizational business performance excellence [73] 


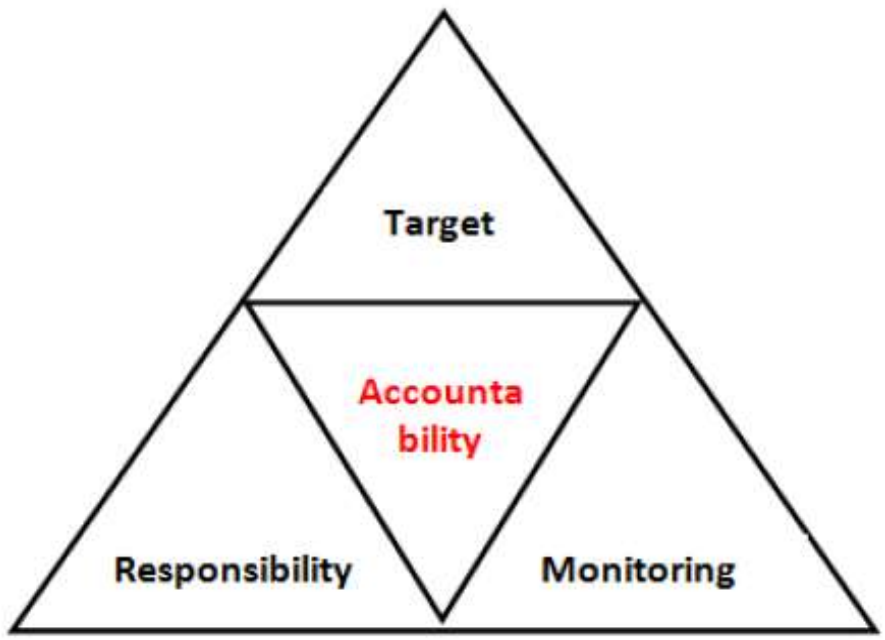

Fig. 3: Major constructs of Theory A [73].

Major Elements of Theory of Accountability \& Compensation are :

- (1) Problem identification based on the objectives of the organization

- (2) Planning based on set objectives

- (3) Responsibility setting

- (4) Target setting

- (5) Resource allocation

- (6) Working strategy

- (7) Role model

- (8) Motivation

- (9) Monitoring \& Guiding

- (10) Performance measurement metric

- (11) Accountability

Theory of Accountability argues that excellence in organizational performance through quality productivity and quality service can be achieved by implementing the components of it effectively. Hence it stresses on human development, motivation, and accountability for ensured individual and organizational success.

\section{THEORY OF ACCOUNTABILITY (THEORY A) APPLIED TO ORGANIZATIONAL PERFORMANCE :}

\subsection{Business Excellency \& Organizational Performance :}

According to the Theory of Accountability, the relation between Business excellence and Organizational performance with Organizational accountability and Organizational objectives are depicted in figure 1. The business excellence can be derived from exceptional organizational performance, which depends on organizational internal and external accountability which in turn depends on organizational set objectives [74].

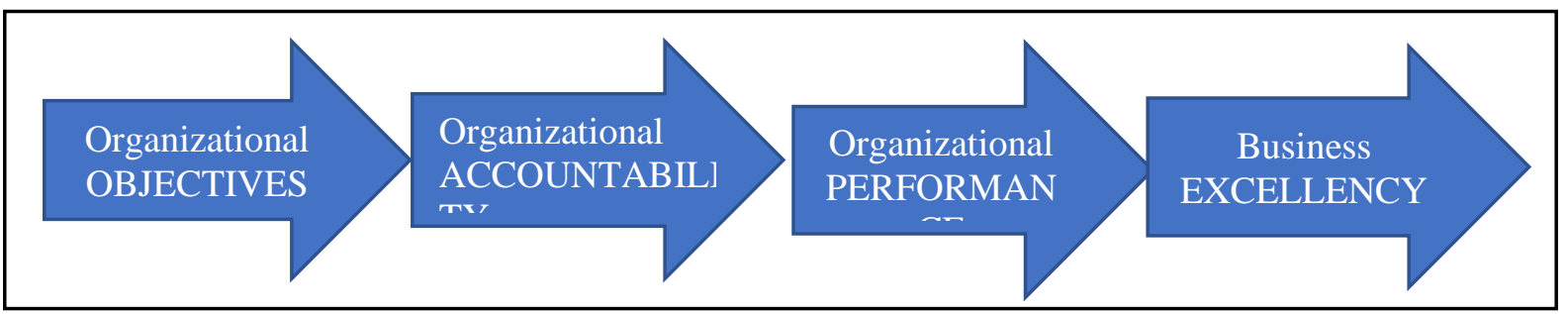

Fig. 4 : Relation between Business excellency and Organizational performance with Organizational accountability and Organizational objectives 
The major steps to be followed while implementing Theory of Accountability in an organization to achieve performance excellence are :

(1) Planning :

Planning is an important determinant component of the Theory of Accountability and the first step for transforming the organization as per its vision, mission, and objectives. Planning supports to optimize the employee's contribution to the organization by understanding the organizational objectives. By involving employees of the organization in setting or refining the objectives, the leaders can encourage their employees to think and contribute innovatively. The planning strategy of Theory A also focuses on how organizations can develop and implement a monopoly or competitive business strategy in their business to achieve excellence. Theory A also suggests that the planning component should involve employees in analyzing the organizational strengths, limitations, opportunities, and challenges and involving themselves in organizational transformation into highly productive and sustainable.

\section{(2) Target Setting :}

Target setting is another determinant component of the Theory of Accountability. Accordingly, the time-bound targets have to be set both teams and individuals in an organization to improve performance. The time-bound target should be set and communicated to every employee for quarterly, half-yearly, or annually based on institutional policy to allow everyone to prepare and devote their efforts toward dedicated performance.

\section{(3) Motivation :}

This component of the Theory of Accountability will help employees to discover their hidden potential through self-exploration. Based on the target of individuals and teams, the organization should develop implementation policies and should identify various motivational strategies which can overcome the weakness of the employees and encourages them to outperform with others. This should also involve factors which appreciate individuals to contribute through collaboration and various task based strategies for better performance toward achieving organizational excellence.

\section{(4) Work Strategies :}

Work strategy provides a time-bound plan for teams and individuals to reach their targets. Re-defining targets based on successive fulfilment to reach excellence is another part of work strategy. Work strategy also supports to collaborate other teams and people simultaneously as a multitasking model.

\section{(5) Responsibility :}

According to this component, when employees show their responsibility towards achieving the organizational objectives, productivity and service quality of the organization will enhance, which in turn will improve customer satisfaction and contribute to customer delight. Organizations should identify those employees who have the ability to take responsibility by themselves and encourage them for enhanced contribution.

\section{(6) Role model :}

Role models are essential in the organization to prove that given targets can be achievable. Based on high set targets, employees may have fear of its realization. By showing exceptional achievers who contribute highest to the organization as role models, either from internal or external to the organization in a similar field, the organization should prove that set targets are achievable. Role models are those who inspire every employee through their higher productivity despite constraints. Such role model based organizational targets inspires the employees to perform better by contributing to the organizational business.

\section{(7) Monitoring :}

Monitoring the performance is another component of the Theory of accountability. In time monitoring the performance and comparing it with planned target and further motivating by the team leaders or superiors to accelerate the productivity of the organization. This will create responsibility among employees and avoid redundancy. It is argued that continuous monitoring and guiding process provides confidence among the employees and will keep team performance high. 


\section{(8) Accountability :}

Accountability is the final component and last step in the Theory of Accountability. Accountability should be fixed to every employee of the organization, including the team leaders so that satisfaction and justice among the employees can be maintained. Accountability should be decided by the organization based on its policy and is inconsistence with the performance of individual employees. Accountability may be either positive or negative depending on a strict developed policy for achievers and losers, respectively.

\subsection{Factors affecting Organizational Business Excellence :}

According to Theory A, the following factors affect the employee performance of an organization [74]. (1) Organizational Objectives \& Business Excellence :

Identifying organizational objectives for sustainable business by providing exceptional quality to customers to satisfy and delight them is the foundation of achieving organizational business excellence.

\section{(2) Planning based on set objectives :}

Planning and implementation based on set objectives are essential for following survival, sustainable, completive, or monopoly strategy to differentiate the organization to achieve business excellence.

\section{(3) Responsibility \& Target setting :}

Recruiting employees who can be responsible for achieving organizational objectives will definitely contribute to enhancing productivity at lower cost and improve the quality of service up to the satisfaction of customers. Responsible and motivated employees with focussed target will contribute to quality production and service in an organization and satisfy as well as delight their customers and also fulfill the expectations of their suppliers and collaborators. This in turn contributes toward achieving their organizational excellence.

\section{(4) Resource allocation \& Motivation :}

The basic intention of Theory A is to improve employee performance by means of motivating them for optimum contribution. This will also help them to discover their own potential through self-exploration. The organization should develop and implement various policies and allocate required resources to the employees to optimize their contribution toward improving organizational performance from both customers and the public point of view. Motivation may include support to identify weaknesses, encouragement to come at par with others, appreciation of the fair performance, encouragement for collaborative approaches, developing task-based strategies, opportunity for advancement of better performers, etc [83]. Through systematic resource allocation and motivation, organizations can boost employee performance and enhance service quality.

\section{(5) Working strategy based on Role model :}

Strategy is a systematic plan to reach the target and to ensure success. By developing a suitable working strategy for maximum performance compared to role model performance, an organization can accelerate its employee involvement in quality service. People who outperform by redefining their targets and inspire others in the organization are treated as role models. Such people will quickly grow and get promotions vertically along with organization growth. Such individual growth strategies have seen in many growing organizations which want to achieve business excellence. Strategies like teamwork through collaborating with other people, working on more than one sub-activities simultaneously are helping the organization to achieve organizational excellence by improving service quality and productivity [84].

\section{(6) Monitoring \& Guiding :}

Performance monitoring and comparing with universal standards and best practices is essential in every organization which wants to excel in service quality. The theory of accountability focuses on monitoring employees contributions by superiors and guiding them in time for corrections. This will stimulate individual and organizational performance toward customer satisfaction and delight by continuous and radical improvements in the quality of products and services [85]. 


\section{(7) Performance measurement metric \& Accountability :}

In order to ensure excellence in business, organizations should continuously measure the performance of their products and services against global standards as well as their competitors and take corrective measures if there is a lagging. There should be a properly developed quality and performance measurement system using standard and acceptable metrics. Based on performance measurement of individuals and teams, accountability should be set for everyone including the head of the departments and heads of the organizations. Consistency in individual and team performance leads to organizational business excellence. Every organization should develop a policy for accountability, which should be positive or negative for achievers of targets or failures to achieve the targets, respectively [86].

\section{COMPARISON OF THEORY OF ACCOUNTABILITY \& BALDRIGE CRITERIA FOR PERFORMANCE EXCELLENCE :}

The Theory of Accountability, when implemented systematically can support an organization to perform better and to achieve its objective of reaching to business performance excellence. An organization can develop a better and successful leader by means of a productive environment where employees are responsible for contributing excellence to the productivity and effectiveness of service quality through self-motivation, dedication identified. and self-set targets by seeing effective role models who are exceptional performers [86-88]. Theory of accountability promotes organizational performance excellence through its concept, procedures, and applicability in any kind of organization in different industries. In this section, the Theory of Accountability for achieving performance excellence in organizations is compared with the American Baldridge Criteria of performance excellence.

\subsection{Conceptual Comparison :}

Table 9 lists the conceptual criterion of American Baldridge Criteria of performance excellence are compared with the Theory of Accountability for achieving performance excellence in organizations. Here, finally, Baldridge criteria focus on measuring output results whereas the Theory of Accountability focuses on achieving organizational excellence.

Table 9: Comparison of 7 Criterion of Performance Excellence

\begin{tabular}{|l|l|l|}
\hline S. No. & $\begin{array}{l}\text { Baldrige Criteria for Performance } \\
\text { Excellence }\end{array}$ & $\begin{array}{l}\text { Theory of Accountability for Performance } \\
\text { Excellence }\end{array}$ \\
\hline 1 & Leadership & Organizational Objectives \\
\hline 2 & Strategic planning & Planning based on set objectives \\
\hline 3 & Customer focus & Responsibility and Target setting \\
\hline 4 & $\begin{array}{l}\text { Performance measurement, analysis, and } \\
\text { knowledge management }\end{array}$ & $\begin{array}{l}\text { Resource allocation and } \\
\text { Motivation }\end{array}$ \\
\hline 5 & Workforce focus & Working strategy based on Role model \\
\hline 6 & Process management & Monitoring and Guiding \\
\hline 7 & Results & $\begin{array}{l}\text { Performance measurement metric \& } \\
\text { Accountability }\end{array}$ \\
\hline
\end{tabular}

\subsection{Procedural Comparison :}

Table 10 lists the comparison of the procedures of developing responses in the case of Baldridge Criteria of performance excellence and Theory of Accountability for achieving performance excellence. It can be argued that the Theory of Accountability has a straightforward procedure to achieve organizational excellence like Baldrige criteria.

Table 10 : Comparison of 7 procedures of developing responses

\begin{tabular}{|l|l|l|}
\hline S. No. & $\begin{array}{l}\text { Procedures for developing as per } \\
\text { American Baldrige Criteria }\end{array}$ & $\begin{array}{l}\text { Procedures for developing as per Theory of } \\
\text { Accountability }\end{array}$ \\
\hline 1 & $\begin{array}{l}\text { Identify the scope of the assessment: will } \\
\text { it cover the entire organization, a subunit, }\end{array}$ & $\begin{array}{l}\text { Identify organizational objectives from each } \\
\text { stakeholder and validate them from top }\end{array}$ \\
\hline
\end{tabular}




\begin{tabular}{|c|c|c|}
\hline & a division, or a department? & management. \\
\hline 2 & $\begin{array}{l}\text { Select seven champions, one for each } \\
\text { Criteria category, to lead a team in } \\
\text { preparing responses to the questions in } \\
\text { the category. Have the champions write } \\
\text { your Organizational Profile. }\end{array}$ & $\begin{array}{l}\text { Planning based on set objectives by developing } \\
\text { both short term and long term plans by means } \\
\text { of organizational analysis, environmental } \\
\text { analysis, identifying, evaluating, and choosing } \\
\text { optimum plans. }\end{array}$ \\
\hline 3 & $\begin{array}{l}\text { Form category teams. Have the members } \\
\text { collect data and information to answer } \\
\text { the questions in their respective } \\
\text { categories, referring to the notes after } \\
\text { each item and the Category and Item } \\
\text { Commentary as guides. }\end{array}$ & $\begin{array}{l}\text { Responsibility \& Target setting by Recruiting } \\
\text { suitable people who are eligible with skills and } \\
\text { confidence for dedicated performance and } \\
\text { setting their target with responsibility. }\end{array}$ \\
\hline 4 & $\begin{array}{l}\text { Have the teams share their answers to the } \\
\text { Criteria questions and identify common } \\
\text { themes and missing linkages. }\end{array}$ & $\begin{array}{l}\text { Motivating the employees by providing } \\
\text { required resources, systems, and technology } \\
\text { for maximizing productivity and performance. }\end{array}$ \\
\hline 5 & $\begin{array}{l}\text { Have each category team create and } \\
\text { communicate an action plan for } \\
\text { improvement based on their answers. } \\
\text { Consider using the Self-Analysis } \\
\text { Worksheet, a Word file that may be } \\
\text { downloaded for free from our website. }\end{array}$ & $\begin{array}{l}\text { Working strategy based on the Role model: } \\
\text { Every employee should develop a working } \\
\text { strategy with the guidance of their leaders or } \\
\text { superiors who may be role models in the } \\
\text { organization in order to reach the } \\
\text { organizational goal of providing excellent } \\
\text { services to the customers and hence to achieve } \\
\text { business excellence. }\end{array}$ \\
\hline 6 & $\begin{array}{l}\text { Have the seven champions and other } \\
\text { senior leaders build an overall action plan } \\
\text { based on overall organizational priorities. }\end{array}$ & $\begin{array}{l}\text { Continuous monitoring of the performance of } \\
\text { an individual employee is essential by } \\
\text { superiors for keeping them on track for not only } \\
\text { meeting their targets but more than that for } \\
\text { customer and collaborator delight. }\end{array}$ \\
\hline 7 & $\begin{array}{l}\text { Evaluate the self-assessment process, and } \\
\text { identify possible improvements. Involve } \\
\text { senior leaders, champions, and teams. } \\
\text { The teams will need to collaborate to } \\
\text { address questions that link the categories } \\
\text { to each other. }\end{array}$ & $\begin{array}{l}\text { The last stage of the theory of accountability } \\
\text { with measuring the performance of individuals } \\
\text { by developing suitable metrics and offering a } \\
\text { performance based compensation system. This } \\
\text { stage reward employees who reach the target } \\
\text { and punish the employees who fail to reach the } \\
\text { target. Such an accountability system keeps the } \\
\text { employees alert and demands the best } \\
\text { performance, which in turn contributes to } \\
\text { organizational business excellence. }\end{array}$ \\
\hline
\end{tabular}

\subsection{Comparison using ABCD framework :}

$\mathrm{ABCD}$ analysis is developed by Aithal et al $[89,90]$ during 2016 for analyzing advantages, benefits, constraints, and disadvantages (or drawbacks) of a system, concept, idea, product, service, material, process, or strategy from related stakeholders' point of view. The format of ABCD analysis can be qualitative or quantitative. Qualitative $\mathrm{ABCD}$ analysis consists of listing the advantages, benefits, constraints, and drawbacks of the issue to be discussed from various stakeholder point of view [91100]. Qualitative $A B C D$ analysis consists of factors and elemental analysis to identify various affecting factors and critical constituent elements [101-106]. Here, the Baldrige Criteria and Theory of Accountability are compared for performance excellence using the Qualitative ABCD analysis framework and are listed in table 11.

Table 11 : Qualitative ABCD analysis of Baldrige Criteria and Theory of Accountability

\begin{tabular}{|l|l|l|}
\hline Constructs & American Baldrige Criteria & Theory of Accountability \\
\hline Advantages & $\begin{array}{l}\text { (1) Stress on organizational leadership } \\
\text { (2) Importance of organizational }\end{array}$ & $\begin{array}{l}\text { (1) Stress on organizational objectives } \\
\text { leading business excellence. }\end{array}$ \\
\hline
\end{tabular}


planning

(3) Customer focus leads to customer satisfaction and delight.

(4) Measurement and analysis of performance supports systematic knowledge management for current future decisions.

(5) Focus on workforce provides special attention, regulations, training, employee engagement tactics and strategies.

(6) Process management and innovation using technology provides automation and quality improvement.

(7) Output results of the organizational performance provides business success.

\begin{tabular}{|c|c|}
\hline Benefits & $\begin{array}{l}\text { (1) Visionary leader is a boon to the } \\
\text { organization and the foundation for } \\
\text { reaching business excellency } \\
\text { (2) Organizational planning leads to its } \\
\text { preparedness to face future challenges. } \\
\text { (3) Customer satisfaction and delight } \\
\text { gives the benefit of retaining existing } \\
\text { customers and attracting new } \\
\text { customers. This will also create positive } \\
\text { public perception and goodwill. }\end{array}$ \\
\hline
\end{tabular}

(4) Knowledge management leads organizational learning and helps to improve decision making process.

(5) Focus on workforce leads improvement in workforce facilities and its empowerment. This improves contribution to organizational performance leading to business excellence.

(6) Innovative process management leads differentiation and lowering the cost.

(7) Sustainable output result of extraordinary organizational performance leads customer satisfaction, customer delight and creates consistent brand for achieving business excellence.

\section{Constraints}

(1) Organizational current performance depends on current leadership which increases the responsibility of leaders.

(2) Systematics Implementation of planning through identifying committed employees
(2) Importance of organizational planning based on set objectives.

(3) Responsibility and target setting lead to improved performance towards productivity and satisfactory service to the customers.

(4) Resource allocation \&

Motivation gives support for quality service and job satisfaction

(5) Working strategy based on Role model simulates to fix a high goal and boost confidence.

(6) Monitoring \& Guiding supports the employees psychologically.

(7) Performance measurement by suitable metric and making accountable for individuals' contribution both positively and negatively is the important and final step.

(1) Organizational objectives based business excellence creates goodwill from customers and society.

(2) Optimum performance by employees coincided with both individual and organizational goals.

(3) Setting targets and fixing accountability ensures creativity and hard work.

(4) Employee assumes responsibility utilizing opportunity to perform

(5) Focussed challenge through role model assures performance and ensures success.

(6) Continuous monitoring ensures accelerated progress in the task.

(7) Accountability results in sustainable organizational effectiveness.

(8) Theory of Accountability improves organizational excellence through individual excellency.

(9) Focus on the critical success factors like target setting by showing the role model, motivating and monitoring, and accountability based on output results of individuals and teams certainly improves the organizational performance.

(1) Not all organizations have strong and committed leadership.

(2) Differentiating talents are difficult in complex organizations

(3) Organizational and environmental constraints may affect resource 
(3) Customer satisfaction and delight is complicated aspect due to changes in customer perception.

(4) Performance measurement, analysis and knowledge management needs development of effective metric and use of latest technologies.

(5) Focus on workforce needs resources, continuous training, motivational tactics, and role models for extra-ordinary performance.

(6) Innovation in Process management need suitable proprietary technology and efficient, long term committed \& extraordinary employees.

(7) Organizational excellence and sustainable success through innovative technology, highly motivated employees, committed leaders, and optimum business model is a challenging proposition in many industries and industry sectors due to changes in perception of customers.

\begin{tabular}{|l|l|}
\hline Drawbacks & $\begin{array}{l}\text { (1) Weak leader spoils the fate of } \\
\text { organization }\end{array}$ \\
(2) The fate emp
\end{tabular}

(2) The fate of employees depends on nature of leader.

(3) Achieving customer delight is costly, complex, and time consuming process.

(4) Performance measurement, analysis, and knowledge management is costly and long term process in organization and need special focus.

(5) Focus on workforce by creating extra ordinary working environment is difficult in certain industries due to resource constraints and investment fear of future uncertainties.

(6) Innovation in processes needs competitive technology and huge investment and risk.

(7) Maintaining excellence is difficult based on maintaining sustainable organizational output due to changes in internal performance and external stakeholder's expectations. allocation.

(4) Not all employees may be proactive in setting targets. High target may hamper the customer delight.

(5) The absence of a role model may feed negative thinking in the mind of employees. Jealousy towards role models may hamper positive spirit.

(6) There may be hesitation in accepting theory A as a basic philosophy for motivation and management.

(7) Setting and implementing accountability is difficult based on employee social conditions in the society.

(8) Identification \& selection of optimum performers as employees is difficult.

(9) Organizational excellence and sustainable success through innovative technology, highly motivated employees, committed leaders, and optimum business model is a challenging proposition in many industries and industry sectors depend on the attitude and perception of top leaders.

(1) Target setting would be a difficult process for some employees and inability to realize targets may give frustration.

(2) All employees may not assume responsibility easily.

(3) Some individuals fail to be motivated by creativity.

(4) Demands committed leaders as managers and role models.

(5) Log process and takes time to generate output from slow performers. (6) Some individuals may be pessimistic about their own potential.

(7) Negative accountability is difficult to accept in society.

(8) Maintaining excellence is difficult based on maintaining sustainable organizational output due to changes in internal performance and external stakeholder's expectations.

\section{DISCUSSIONS :}


Table 12 compares the Attributes of Business Excellence Models with the attributes of Organizational Theory of Accountability for superior organizational performance.

Table 12 : Comparison of the Attributes of Business Excellence Models with the attributes of Organizational Theory of Accountability

\begin{tabular}{|c|c|c|}
\hline S. No. & Core values and Concepts & Core values and Concepts \\
\hline 1 & $\begin{array}{l}\text { Visionary leadership: } \\
\text { Senior leaders should involve in setting the } \\
\text { directions to create customer focus business } \\
\text { with clear and visible organizational values } \\
\text { and organizational expectations to all } \\
\text { stakeholders of the organization. }\end{array}$ & $\begin{array}{l}\text { Problem identification based on the } \\
\text { objectives of the organization: } \\
\text { The senior leaders set clear objectives of the } \\
\text { organization and decide the values and } \\
\text { traditions to be inculcated among the } \\
\text { employees to provide satisfactory and } \\
\text { delightful service to the customers. }\end{array}$ \\
\hline 2 & $\begin{array}{l}\text { Customer-driven excellence: } \\
\text { Customers judge the quality and } \\
\text { performance of the organizational products } \\
\text { or services. Organization should focus on } \\
\text { improving all product features and } \\
\text { characteristics and all modes of customer } \\
\text { access and support that contributes value } \\
\text { from customer point of view. }\end{array}$ & $\begin{array}{l}\text { Planning based on set objectives: } \\
\text { Strategic planning and procedure to realize } \\
\text { the objectives should be developed to } \\
\text { identify, acquire, and retain appropriate } \\
\text { human resources and systems and further to } \\
\text { empower employees. This creates a } \\
\text { supportive working atmosphere in the } \\
\text { organization to provide better service. }\end{array}$ \\
\hline 3 & $\begin{array}{l}\text { Organizational and personal learning: } \\
\text { Organizational and personal learning leads } \\
\text { to improving organizational performance } \\
\text { through sharing knowledge via systematic } \\
\text { processes, using both continuous } \\
\text { improvement of existing approaches and } \\
\text { radical changes lading to new goals and } \\
\text { approaches. }\end{array}$ & $\begin{array}{l}\text { Responsibility setting: } \\
\text { Identifying and distributing the various } \\
\text { responsibilities for suitable people for } \\
\text { suitable work is the major component of the } \\
\text { theory of accountability. People who are } \\
\text { responsible are more determined and } \\
\text { dedicated to achieving their targets. }\end{array}$ \\
\hline 4 & $\begin{array}{l}\text { Valuing workforce members and } \\
\text { partners: } \\
\text { Engaging the workforce and valuing the } \\
\text { partners with clear directions and } \\
\text { performance accountability leads } \\
\text { organizational success. }\end{array}$ & $\begin{array}{l}\text { Target setting: } \\
\text { Leaders should set the target for every } \\
\text { employee or team and create an } \\
\text { environment to archive it. Keeping the } \\
\text { target high and supporting continuously to } \\
\text { achieve it is the characteristic of high- } \\
\text { performing leaders. }\end{array}$ \\
\hline 5 & $\begin{array}{l}\text { Agility: } \\
\text { Agility is the capacity of leaders and } \\
\text { employees for rapid changes and flexibility } \\
\text { in internal and external environment which } \\
\text { gives success in ever changing globally } \\
\text { competitive environment. }\end{array}$ & $\begin{array}{l}\text { Resource allocation: } \\
\text { Allocation of the right resources at the right } \\
\text { time motivates the employees to achieve } \\
\text { their targets. }\end{array}$ \\
\hline 6 & $\begin{array}{l}\text { Focus on the future: } \\
\text { Organizational sustainability and progress } \\
\text { depend on understanding the future } \\
\text { opportunities in market place both short term } \\
\text { and long term perspectives. }\end{array}$ & $\begin{array}{l}\text { Working strategy: } \\
\text { Every team and employee should be } \\
\text { encouraged to develop working strategies to } \\
\text { plan, execute, and even outperform with the } \\
\text { responsibility to achieve their targets. }\end{array}$ \\
\hline 7 & $\begin{array}{l}\text { Managing for innovation: } \\
\text { Innovation is key factor to make meaningful } \\
\text { changes in products, services, programs, } \\
\text { operations, processes, and business models } \\
\text { to create new value for stakeholders. }\end{array}$ & $\begin{array}{l}\text { Role model: } \\
\text { Proving the possibility of achieving the } \\
\text { target and further increasing the target is the } \\
\text { responsibility of the leader by showing a } \\
\text { role model in the same field who is an } \\
\text { exceptional achiever. A role model can be } \\
\text { from internal to the organization or external }\end{array}$ \\
\hline
\end{tabular}




\begin{tabular}{|c|c|c|}
\hline & & $\begin{array}{l}\text { to the organization. Showing the role model } \\
\text { is the main component of the inspiration of } \\
\text { employees. }\end{array}$ \\
\hline 8 & $\begin{array}{l}\text { Management by fact: } \\
\text { Continuous measurement of organizational } \\
\text { performance is essential. Useful information } \\
\text { should be derived from organizations key } \\
\text { processes, output, and results. }\end{array}$ & $\begin{array}{l}\text { Motivation : } \\
\text { The motivation of employees to perform } \\
\text { better and to provide faithful service is } \\
\text { another primary requirement in business } \\
\text { organizations. Organizational performance } \\
\text { depends on the effective contribution of } \\
\text { positive thinking employees. Both customer } \\
\text { satisfaction and delight-ness are possible } \\
\text { only through highly motivated employees. }\end{array}$ \\
\hline 9 & $\begin{array}{l}\text { Societal responsibility: } \\
\text { Organizations through its leaders should } \\
\text { show responsibilities towards public through } \\
\text { its ethical behaviour and providing social } \\
\text { benefits. }\end{array}$ & $\begin{array}{l}\text { Monitoring \& Guiding: } \\
\text { Team leaders and managers should } \\
\text { continuously monitor the performance of } \\
\text { the employees and guide them towards } \\
\text { achieving their targets. It is also required to } \\
\text { redefine the goal and target of individual } \\
\text { and group performance to achieve } \\
\text { performance excellence. }\end{array}$ \\
\hline 10 & $\begin{array}{l}\text { Focus on results and creating value: } \\
\text { The performance of an organization is } \\
\text { measured through its output results, the } \\
\text { organization should focus on its key results } \\
\text { which create value for its stakeholders. }\end{array}$ & $\begin{array}{l}\text { Performance measurement metric: } \\
\text { The performance of individuals, teams, and } \\
\text { hence the organization should be measured } \\
\text { using identified measurable parameters } \\
\text { (metric) which decide the output results } \\
\text { and the value created by individuals and } \\
\text { the teams of the organization. }\end{array}$ \\
\hline 11 & $\begin{array}{l}\text { Systems perspective: } \\
\text { System model of organization with known } \\
\text { inputs, processes, output, and environment } \\
\text { allows any organization to manage } \\
\text { holistically and to understand how its } \\
\text { components interact and align to achieve } \\
\text { success. }\end{array}$ & $\begin{array}{l}\text { Accountability: } \\
\text { The business excellence of an organization } \\
\text { depends on the Performance of individuals } \\
\text { and teams towards achieving organizational } \\
\text { goals by reaching the allotted targets } \\
\text { effectively and efficiently. If employees } \\
\text { overperform, the customers can get } \\
\text { delighted. Through proper set } \\
\text { accountability both in a positive and } \\
\text { negative manner, the employees get } \\
\text { inspiration and stimulation as well as } \\
\text { pressure to become a winner through } \\
\text { exceptional performance. This leads to } \\
\text { organizational success as a whole. }\end{array}$ \\
\hline
\end{tabular}

\section{CONCLUSION :}

Theory of Accountability has specific and strong components than American Baldrige Criteria of organizational business excellence. The components of the theory of accountability are complementary to achieve the Baldrige Criteria in an organization. Theory of accountability builds a strong pillar to an organization to achieve components of the Baldrige model in the process of improved performance thereby achieving organizational excellence. Similarly, one can argue that other business excellence criteria also can be achieved by implementing theory of accountability in the organization. The theory of accountability components plays a major role in organizational productivity and stakeholders' satisfaction. Organizations of the $21^{\text {st }}$ century can invest their resources and efforts to implement the Theory of Accountability model for survival, sustainability, competition, monopoly, and growth and expansion in the global scenario. 


\section{REFERENCES}

[1] Rumelt, R. P., Schendel, D., \& Teece, D. J. (1991). Strategic management and economics. Strategic management journal, 12(S2), 5-29.

[2] Martensen, A., \& Dahlgaard, J. J. (1999). Strategy and planning for innovation management-a business excellence approach. International Journal of quality \& reliability Management, 16(8), 734-755.

[3] Aithal, P. S., \& Kumar, P. M. (2015). Black Ocean Strategy-A Probe into a new type of Strategy used for Organizational Success. GE-International Journal of Management Research (GEIJMR), 3(8), 45-65.

[4] Shengtian Hou (2007). Green ocean strategy: Obtaining sustainable competitive advantage, pp. $183-197$

[5] Han Kim, W, Renee Mauborgne (2006). Blue Ocean Strategy, pp. 29 - 32.

[6] Porter M. E. (1997). Competitive strategy. Measuring Business Excellence, 1(2), 12 - 17.

[7] Aithal, P. S. (2016). The concept of ideal strategy and its realization using white ocean mixed strategy. International Journal of Management Sciences and Business Research, 5(4), 171-179.

[8] Adebanjo, D. and Mann, R. (2008). Business Excellence. BPIR Management Brief. Palmerston North, New Zealand: BPIR.

[9] Kanji, G. K. (1998). Measurement of business excellence. Total Quality Management, 9(7), 633643.

[10] Aithal, P. S., \& Acharya, R. K. (2016). Strategic Management Models \& Indian Epics. International Journal of Management Sciences and Business Research, 5(4), 180-189.

[11] Aithal, P. S., \& Aithal, S. (2019). Strategic Management of Universal Technologies for Redefining Productivity \& Performance. International Journal of Applied Engineering and Management Letters (IJAEML), 3(2), 81-95.

[12] Lorino P. (1997). Méthodes et pratiques de la performance [Performance Methods and Practices], Paris, Les Editions d'Organisation, Third Edition, pp. 1-520, ISBN 2-7081-2928-7.

[13] Rolstadas A. (1998). Entreprise Performance Measurement. International Journal of Operations and Production Management, 18(9-10), 989-999.

[14] Folan P., Browne J. \& Jagdev H. (2007). Performance: It's Meaning and Content for Today's Business Research. Computers in Industry, 58(7), 605-620.

[15] Richard, Pierre J., Devinney, Timothy M., Yip, George S., Johnson, Gerry (2009). Measuring Organizational Performance: Towards Methodological Best Practice. Journal of Management. SAGE Publications. 35(3), 718-804.

[16] Elena-Iuliana, I., \& Maria, C. (2016). Organizational Performance - A Concept that Self-Seeks to find itself. Annals of' Constantin Brancusi'University of Targu-Jiu. Economy Series, 1(4), 179183. https://www.utgjiu.ro/revista/ec/pdf/2016-04/27_Ion,\%20Criveanu.pdf

[17] Puteh, F., Kaliannan, M., \& Alam, N. (2016). Employee core competencies and organisational excellence: An interpretative analysis. Australian Journal of Business and Economic Studies, 2(1), 45-55.

[18] Tickle, M., Mann, R., \& Adebanjo, D. (2016). Deploying business excellence-success factors for high performance. International Journal of Quality \& Reliability Management, 33(2), 97-230.

[19] Kanji, G. K. (2002). Business excellence: make it happen. Total Quality Management, 13(8), 11151124.

[20] Kanji, G. K., \& e Sa', P. M. (2001). Measuring leadership excellence. Total Quality Management, 12(6), 701-718. 
[21] Oakland, J. S., \& Tanner, S. J. (2008). The relationship between business excellence and performance-An empirical study using Kanji's leadership excellence model. Total Quality Management, 19(7-8), 733-749.

[22] Hadi, A. A., Abdullah, H., \& Atshan, N. (2019). Effect of organisational integrity and leadership behaviour on organisational excellence. International Journal of Organizational Analysis. International Journal of Organizational Analysis, 27(4), 972-985.

[23] Bauer, J., Falshaw, R., \& Oakland, J. S. (2005). Implementing business excellence. Total Quality Management \& Business Excellence, 16(4), 543-553.

[24] Sendjaya, S. (2015). Personal and Organizational Excellence through Servant Leadership Learning to Serve, Serving to Lead, Leading to Transform. Springer. ISBN 978-3-319-16195-2.

[25] Boussalem, A. (2015). Employees' Empowerment as an Approach to Achieve the Business Excellence-Case Study on Algerian Communications Company. 265(2453), 1-11.

[26] Badruddin, A. (2016). Achieving Business Excellence by Managing Men at Workplace. ADHYAYAN: A Journal of Management Sciences, 6(1), 82-90.

[27] Meško Štok, Z., Markič, M., Bertoncelj, A., \& Meško, M. (2010). Elements of organizational culture leading to business excellence. Zbornik radova Ekonomskog fakulteta u Rijeci: časopis za ekonomsku teoriju i praksu, 28(2), 303-318.

[28] Sila, I., \& Ebrahimpour, M. (2002). An investigation of the total quality management survey based research published between 1989 and 2000: A literature review. International Journal of Quality \& Reliability Management, 19(6/7), 902-970.

[29] Lo, Q. Q., \& Chai, K. H. (2012). Quantitative analysis of quality management literature published in total quality management and business excellence (1996-2010). Total Quality Management \& Business Excellence, 23(5-6), 629-651.

[30] Lee, P. M. (2002). Sustaining business excellence through a framework of best practices in TQM. The TQM magazine, 14(3), 142-149.

[31] Androniceanu, A. (2017). The three-dimensional approach of Total Quality Management, an essential strategic option for business excellence. Amfiteatru Economic, 19(44), 61-78.

[32] Hafeez, K., Malak, N., \& Abdelmeguid, H. (2006). A framework for TQM to achieve business excellence. Total Quality Management and Business Excellence, 17(9), 1213-1229.

[33] Vora, M. K. (2002). Business excellence through quality management. Total Quality Management, 13(8), 1151-1159.

[34] Toma, S. G., \& Naruo, S. (2017). Total quality management and business excellence: the best practices at Toyota Motor Corporation. Amfiteatru Economic Journal, 19(45), 566-580.

[35] Savolainen, T. (2000). Leadership strategies for gaining business excellence through total quality management: a Finnish case study. Total Quality Management, 11(2), 211-226.

[36] Oakland, J. (2005). From quality to excellence in the 21st century. Total Quality Management and Business Excellence, 16(8-9), 1053-1060.

[37] Dinu, V. (2017). Quality management and business excellence. Amfiteatru Economic Journal, 19(44), 5-7.

[38] Lu, D., Betts, A., \& Croom, S. (2011). Re-investigating business excellence: Values, measures and a framework. Total Quality Management \& Business Excellence, 22(12), 1263-1276.

[39] Collins J., 2001. Good to Great, Random House Business Books: Sydney.

[40] Meško Štok, Z., Markič, M., Bertoncelj, A., \& Meško, M. (2010). Elements of organizational culture leading to business excellence. Zbornik radova Ekonomskog fakulteta u Rijeci: časopis za ekonomsku teoriju i praksu, 28(2), 303-318. 
[41] Talwar B. (2009). Comparative study of core values of excellence models vis-à-vis human values. Measuring Business Excellence, 13(4), 34-46.

[42] Mele, C., \& Colurcio, M. (2006). The evolving path of TQM: towards business excellence and stakeholder value. International Journal of Quality \& Reliability Management, 23(5), 464-489.

[43] Jabnoun, N. (2019). A proposed model for sustainable business excellence, Management Decision, $58(2), 221-238$.

[44] Díez, Jose María, Magda Lizet Ochoa, M. Begoña Prieto, and Alicia Santidrián. (2010). Intellectual capital and value creation in Spanish firms. Journal of Intellectual Capital, 11(3), 348-367.

[45] Nourani, M., Devadason, E. S., Kweh, Q. L., \& Lu, W. M. (2017). Business excellence: the managerial and value-creation efficiencies of the insurance companies. Total Quality Management \& Business Excellence, 28(7-8), 879-896.

[46] Hardjono, T. W., \& van Marrewijk, M. (2001). The social dimensions of business excellence. Corporate Environmental Strategy, 8(3), 223-233.

[47] Sharma, A. K., \& Talwar, B. (2005). Corporate social responsibility: modern vis-à-vis Vedic approach. Measuring Business Excellence, 9(1), 35-45.

[48] Achtenhagen, L., Melin, L., \& Naldi, L. (2013). Dynamics of business models-strategizing, critical capabilities and activities for sustained value creation. Long range planning, 46(6), 427-442.

[49] Kianto, A., Ritala, P., Spender, J.-C., Vanhala, M. (2014). The interaction of intellectual capital assets and knowledge management practices in organizational value creation. Journal of Intellectual capital. 159(3), 362-375.

[50] Scholer, A. A., \& Higgins, E. T. (2009). Exploring the complexities of value creation: The role of engagement strength. Journal of Consumer Psychology, 19(2), 137-143.

[51] Enquist, B., \& Johnson, M. (2015). The paradigm shift to Business Excellence 2.0. International Journal of Quality and Service Sciences, 7(2-3), 321-333.

[52] Tantalo, C., \& Priem, R. L. (2016). Value creation through stakeholder synergy. Strategic Management Journal, 37(2), 314-329.

[53] Ferdowsian, M. C. (2016). Total business excellence-a new management model for operationalizing excellence. International Journal of Quality \& Reliability Management, 33(7), 942-984.

[54] Fornell, C. (1992). A national customer satisfaction barometer: The Swedish experience. Journal of marketing, 56(1), 6-21.

[55] Torres, E. N., \& Kline, S. (2013). From customer satisfaction to customer delight. International Journal of Contemporary Hospitality Management, 25(5), 642-659.

[56] Popli, S. (2005). Ensuring customer delight: A quality approach to excellence in management education. Quality in Higher Education, 11(1), 17-24.

[57] Kanji, G. K., \& Wallace, W. (2000). Business excellence through customer satisfaction. Total quality management, 11(7), 979-998.

[58] Klefsjö, B., Bergquist, B., \& Garvare, R. (2008). Quality management and business excellence, customers and stakeholders: do we agree on what we are talking about, and does it matter?. The TQM Journal, 20(2), 120-129.

[59] Koc, E. (2006). Total quality management and business excellence in services: The implications of all-inclusive pricing system on internal and external customer satisfaction in the Turkish tourism market. Total Quality Management \& Business Excellence, 17(7), 857-877.

[60] Marquardt, A. (2015). Concepts and realization of customer delight. International Journal of Sales, Retailing \& Marketing, 4(5), 3-13. 
[61] Mihaela Ghicajanu, Sabina Irimie, Laura Marica, Rares Munteanu (2015). Criteria for Excellence in Business. Procedia Economics and Finance, 23(1), 445 - 452.

[62] Khoo, H. H., \& Tan, K. C. (2002). Using the Australian business excellence framework to achieve sustainable business excellence. Corporate Social Responsibility and Environmental Management, 9(4), 196-205.

[63] Prybutok, V. and Cutshall, R. (2004). Malcolm Baldrige National Quality Award leadership model. Industrial Management \& Data Systems, 104(7), 558-566.

[64] Abdulla Badri, M., Selim, H., Alshare, K., Grandon, E. E., Younis, H. and Abdulla, M. (2006). The Baldrige Education Criteria for Performance Excellence Framework: Empirical test and validation. International Journal of Quality \& Reliability Management, 23(9), 1118-1157.

[65] Flynn, B. B., \& Saladin, B. (2001). Further evidence on the validity of the theoretical models underlying the Baldrige criteria. Journal of Operations Management, 19(6), 617-652.

[66] Pannirselvam, G. P. and Ferguson, L. A. (2001). A study of the relationships between the Baldrige categories. International Journal of Quality \& Reliability Management, 18(1), 14-37.

[67] Kim, D. Y., Kumar, V., \& Murphy, S. A. (2010). European foundation for quality management business excellence model. International Journal of Quality \& Reliability Management, 27(6), 684 -701 .

[68] Bhullar, A. S., Gan, C. W., Ang, A. J., Ma, B., Lim, R. Y., \& Toh, M. H. (2014, December). Operational excellence frameworks - Case studies and applicability to SMEs in Singapore. In 2014 IEEE International Conference on Industrial Engineering and Engineering Management (pp. 667-671). IEEE.

[69] https://viewer.ipaper.io/siq/siq-managementmodell-2021/siq-management-model-in-english/ referred on 20/04/2021.

[70] Pearson, H., \& Sutherland, M. (2017). The complexity of the antecedents influencing accountability in organisations. European Business Review, 29(4), 419-439.

[71] Landwehr, C., \& Wood, M. (2019). Reconciling credibility and accountability: how expert bodies achieve credibility through accountability processes. European Politics and Society, 20(1), 66-82.

[72] Aithal, S., \& Kumar, S. (2016). Comparative Analysis of Theory X, Theory Y, Theory Z, and Theory A for Managing People and Performance. International Journal of Scientific Research and Modern Education (IJSRME), 1(1), 803-812.

[73] Aithal, P. S., \& Kumar, P. M. (2019). Autonomy in Higher Education-Towards an Accountability Management Model. International Journal of Management \& Development, 6(10), 166-175.

[74] Aithal, P. S., \& Kumar, P. M. (2016). Organizational behaviour in 21st century-'Theory A' for managing people for performance. IOSR Journal of Business and Management (IOSR$J B M), 18(7), 126-134$.

[75] Aithal, P. S., \& Kumar, P. M. (2016). CCE Approach through ABCD Analysis of 'Theory A' on Organizational Performance. International Journal of Current Research and Modern Education (IJCRME), 1(2), 169-185.

[76] Aithal, P. S., \& Aithal, S. (2018). Study of various General-Purpose Technologies and Their Comparison towards developing Sustainable Society. International Journal of Management, Technology, and Social Sciences (IJMTS), 3(2), 16-33.

[77] Aithal, P. S. (2019). Information Communication \& Computation Technology (ICCT) as a Strategic Tool for Industry Sectors. International Journal of Applied Engineering and Management Letters (IJAEML), 3(2), 65-80.

[78] Aithal, P. S., \& Aithal, S. (2019). Management of ICCT underlying Technologies used for Digital Service Innovation. International Journal of Management, Technology, and Social Sciences 
(IJMTS), 4(2), 110-136.

[79] Aithal, P. S. (2018). Emerging Trends in ICCT as Universal Technology for Survival, Sustainability, Differentiation, Monopoly and Development. In Proceedings of National Conference on Advances in Information Technology, Management, Social Sciences and Education, (pp. 130-141). ISBN No.: 978-81-938040-8-7.

[80] Aithal, P. S. (2021). Review on Ideal Systems \& Technology. Chapter 2, Ideal Systems, Ideal Technology, and their Realization Opportunities using ICCT \& Nanotechnology, pp. 25-82, Srinivas Publication, India, (April 2021). ISBN: 978-81-949961-3-2.

[81] Kanji, G. (2003). A new business excellence model from an old Indian philosophy. Total Quality Management \& Business Excellence, 14(9), 1071-1076.

[82] Sharma, A. K., \& Talwar, B. (2007). Evolution of "universal business excellence model" incorporating Vedic philosophy. Measuring Business Excellence. 11(3), 4-20.

[83] Aithal, P. S., \& Kumar, P. M. (2017). Interconnecting Theory A and ABC Model of Organizational Performance. International Journal of Management, Technology and Social Sciences (IJMTS), Srinivas Publishers, 1(1), 1-13.

[84] Aithal, P. S., \& Kumar, P. M. (2016). Application of Theory A on ABC Model to enhance Organizational Research Productivity in Higher Education. International Journal of Advanced Trends in Engineering and Technology (IJATET), 1(1), 142-150.

[85] Aithal, P. S., \& Aithal, S. (2019). A New Attitude-Behaviour (AB) Theory for Organizational Leadership. International Journal of Management, Technology, and Social Sciences (IJMTS), 4(1), 83-97.

[86] Aithal, P. S. (2018). How to boost faculty research performance in HEI's to improve intellectual property by integrating it with faculty compensation-A 'theory of accountability' based framework. International Journal of Management, Technology, and Social Sciences (IJMTS), 3(2), 130-151.

[87] Aithal, P. S., \& Kumar, P. M. (2017). Integrating Theory A and six thinking hats technique for improved organizational performance. International Journal of Applied Engineering and Management Letters (IJAEML), 1(2), 66-77.

[88] Aithal, P. S., Kumar, P., \& Dillon, M. (2018). How to Improve the Employee Productivity of Banking System in India-A Theory of Accountability Based Analysis. International Journal of Management, Technology, and Social Sciences (IJMTS), 3(2), 87-99.

[89] Aithal, P. S. (2016). Study on ABCD analysis technique for business models, business strategies, operating concepts \& business systems. International Journal in Management and Social Science, 4(1). 95-115.

[90] Aithal, P. S., Shailashree, V. T., \& Suresh Kumar, P. M. (2015). A new ABCD technique to analyze business models \& concepts. International Journal of Management, IT and Engineering, 5(4), 409-423.

[91] Raj, K., \& Aithal, P. S. (2018). Generating Wealth at the Base of the Pyramid-A Study using ABCD Analysis Technique. International Journal of Computational Research and Development (IJCRD), 3(1), 68-76.

[92] Aithal, P. S., Kumar, P. M., \& Shailashree, V. (2016). Factors \& elemental analysis of six thinking hats technique using $\mathrm{ABCD}$ framework. International Journal of Advanced Trends in Engineering and Technology (IJATET), 1(1), 85-95.

[93] Aithal, P. S., Shailashree, V., \& Kumar, P. M. (2016). ABCD analysis of Stage Model in Higher Education. International Journal of Management, IT and Engineering, 6(1), 11-24.

[94] Aithal, P. S. (2017). ABCD Analysis as Research Methodology in Company Case Studies. International Journal of Management, Technology, and Social Sciences (IJMTS), 2(2), 
40-54.

[95] Aithal, P. S., Shailashree, V., \& Kumar, P. M. (2016). The study of new National Institutional Ranking system using ABCD framework. International Journal of Current Research and Modern Education (IJCRME), 1(1). 389-402.

[96] Aithal, P. S., Shailashree, V., \& Kumar, P. M. (2015). Application of ABCD Analysis Model for Black Ocean Strategy. International Journal of Applied Research, 1(10), 331-337.

[97] Aithal, P. S., Shailashree, V., \& Kumar, P. M. (2016). Application of ABCD Analysis Framework on Private University System in India. International Journal of Management Sciences and Business Research, 5(4), 159-170.

[98] Shenoy, V., \& Aithal, P. S. (2016). ABCD Analysis of On-line Campus Placement Model. IRAInternational Journal of Management \& Social Sciences, 5(2), 227-244.

[99] Shenoy, V., \& Aithal, P. S. (2017). Quantitative ABCD Analysis of IEDRA Model of Placement Determination. International Journal of Case Studies in Business, IT and Education (IJCSBE), 1(2), 103-113.

[100] Aithal, P. S. (2017). ABCD Analysis of Recently Announced New Research Indices. International Journal of Management, Technology, and Social Sciences (IJMTS), 1(1), 65-76.

[101] Aithal, P. S., \& Kumar, P. M. (2016). Analysis of Choice Based Credit System in Higher Education. International Journal of Engineering Research and Modern Education (IJERME) 1(1), 278-284.

[102] Shenoy, Varun and Aithal, P. S., (2017). A New Box Framework for E-Campus Interview Training. International Journal of Applied Engineering and Management Letters (IJAEML), 1(2), $17-26$.

[103] Aithal, Architha and Aithal, P. S., (2018). The Concept of Ideal Drug \& Its Realization Opportunity Using present Pharmaceutical Sciences Scenario. International Journal of Health Sciences and Pharmacy (IJHSP), 2(2), 11-26.

[104] Aithal, A., \& Aithal, P. S. (2017). ABCD Analysis of Task Shifting-An optimum Alternative Solution to Professional Healthcare Personnel Shortage. International Journal of Health Sciences and Pharmacy (IJHSP), 1(2), 36-51.

[105] Aithal, S., \& Aithal, P. S. (2016). ABCD analysis of Dye-doped Polymers for Photonic Applications. IRA-International Journal of Applied Sciences, 4(3), 358-378.

[106] Aithal, P. S., Shailashree, V. T, \& Kumar, P. M. (2016). Analysis of ABC Model of Annual Research Productivity using ABCD Framework. International Journal of Current Research and Modern Education (IJCRME), 1(1), 846-858.

$* * * * * * * * * * * * * *$ 